\title{
КОРПОРАТИВНАЯ СИСТЕМА УПРАВЛЕНИЯ АКЦИОНЕРНЫМИ ОБЩЕСТВАМИ В РЕСПУБЛИКЕ БЕЛАРУСЬ
}

\author{
DOI: 10.32620/cher.2018.4.03
}

Постановка проблемы. Развитие экономики Республики Беларусь актуализирует совершенствование корпоративного управления в акционерных обществах, поскольку крупнейшие предприятия республики являются акционерными обществами. Предметом исследования является оценка современного состояния корпоративной системы управления акционерными обществами. Цель статьи - отобразить роль корпоративной системы управления акционерными обществами в Республике Беларусь как инструмента минимизации финансовых рисков. Объект исследования - процессы развития корпоративной системы управления акционерными обществами Республики Беларусь. Mетоды, использованные в исследовании логичекий, сравнительный, аналитический, научно-методологический. Гипотеза исследования состоит в предположении наличия зависимости качества корпоративной системы управления акционерными обществами и их финансовыми рисками. Изложение основного материала. Анализ мирового опыта корпоративной системы управления акционерных обществ свидетельствует, что количество независимых директоров колеблется от 15 до 50\% членов совета директоров (наблюдательного совета) акционерного общества. Это прежде всего требования к эмитентам ценных бумаг, к их корпоративной системе управления. Оригинальность и практическое значение исследования. Банки обязали включить в состав наблюдательного совета не менее двух независимых директоров, предъявив к ним высокие требования. Свою деловую репутацию они должны подтвердить аттестацией в Национальном Банке Республики Беларусь. $B b l-$ воды исследования. Этапы создания системы корпоративного управления акционерными обществами подтверждают наличие достаточной нормативно правовой базы и передового опыта по созданию эффективных систем корпоративного управления, позволяющих управлять рисками, особенно финансовыми и привлекать международных инвесторов.

Ключевые слова:

акционерное общество, корпорация, система управления, финансовый риск, ресурсы.

\section{CORPORATE MANAGEMENT SYSTEM OF SHAREHOLDERS IN THE REPUBLIC OF BELARUS}

Formulation of the problem. The development of the economy of the Republic of Belarus actualizes the improvement of corporate governance in joint-stock companies, since the largest enterprises of the republic are joint-stock companies. The subject of the research is to assess the current state of the corporate management system of joint-stock companies. The aim of the research is to reflect the role of the corporate management system of joint-stock companies in the Republic of Belarus as a tool for minimizing financial risks. The object of research is the development processes of the corporate management system of joint-stock companies of the Republic of Belarus. The methods used of the research are logical, comparative, analytical, scientific and methodological. The hypothesis of the study is the assumption of the dependence of the quality of the corporate management system of joint-stock companies and their financial risks. The statement of basic materials. An analysis of the world experience of the corporate governance system of joint stock companies shows that the number of independent directors ranges from 15 to $50 \%$ of the members of the board of directors (supervisory board) of the joint stock company. These are primarily requirements for issuers of securities, their corporate management system. Originality and practical significance of the research. Banks have obliged to include in the supervisory board at least two independent directors, making high demands on them. They should confirm their business reputation by certification in the National Bank of the Republic of Belarus. Conclusions of the research. The stages of creating a corporate governance system for joint-stock companies confirm the existence of a sufficient regulatory framework and best practices for creating effective corporate governance systems that allow you to manage risks, especially financial ones, and attract international investors.

Key words:

stock company, corporation, management system, financial risk, resources.

\section{КОРПОРАТИВНА СИСТЕМА УПРАВЛІННЯ АКЦІОНЕРНИМ ТОВАРИСТВОМ В РЕСПУБЛІЦ БІЛОРУСЬ}

\footnotetext{
${ }^{1}$ Рабико Ірина Миколаївна, канд. екон. наук, доцент кафедри «Грошовий обіг, кредит та фондовий ринок», Білоруський державний економічний університет, м. Мінськ, Білорусія.

Rabiko Irina, Ph.D. in Economics, Associate Professor of the Money, Credit and Stock Market Department, Belarusian State Economic University, Minsk, Belarus.
}

ORCID ID: 0000-0000-8766-7658

e-mail: irina_rabyko@mail.ru 
Постановка проблеми. Розвиток економіки Республіки Білорусь актуалізує вдосконалення корпоративного управління в акціонерних товариствах, оскільки найбільші підприємства республіки $\epsilon$ акціонерними товариствами. Предметом дослідження є оцінка сучасного стану корпоративної системи управління акціонерними товариствами. Мета сmammi - відобразити роль корпоративної системи управління акціонерними товариствами в Республіці Білорусь як інструменту мінімізації фінансових ризиків. Об'єкт дослідження - процеси розвитку корпоративної системи управління акціонерними товариствами Республіки Білорусь. Методи, використані в дослідженні - логичеких, порівняльний, аналітичний, науково-методологічний. Гіпотеза дослідження полягає в припущенні наявності залежності якості корпоративної системи управління акціонерними товариствами та їх фінансовими ризиками. Виклад основного матеріалу. Аналіз світового досвіду корпоративної системи управління акціонерних товариств свідчить, що кількість незалежних директорів коливається від 15 до 50\% членів ради директорів (наглядової ради) акціонерного товариства. Це перш за все вимоги до емітентів цінних паперів, до їх корпоративної системи управління. Оригінальність $i$ практичне значення дослідження. Банки зобов'язали включити до складу наглядової ради не менше двох незалежних директорів, пред'явивши до них високі вимоги. Свою ділову репутацію вони повинні підтвердити атестацією в Національному Банку Республіки Білорусь. Висновки дослідження. Етапи створення системи корпоративного управління акціонерними товариствами підтверджують наявність достатньої нормативно-правової бази та передового досвіду по створенню ефективних систем корпоративного управління, що дозволяють управляти ризиками, особливо фінансовими $\mathrm{i}$ залучати міжнародних інвесторів.

Ключові слова:

акціонерні товариства, корпорація, система управління, фінансовий ризик, ресурси.

Постановка проблемы. На данном этапе развития экономики Республики Беларусь актуальность совершенствования корпоративного управления в акционерных обществах республики очевидна. Крупнейшие предприятия республики являются акционерными обществами. Эффективная система корпоративного управления дает экономический эффект, делает акционерные общества более устойчивыми к внешнему влиянию, позволяет оценивать и управлять финансовыми рисками при достижении поставленных стратегических целей и одновременно способствует выходу предприятий на международные биржи для привлечения инвестиций и международных инвесторов.

Корпоративное управление акционерным обществом это система взаимодействия ее участников: акционеров, органов управления, контрольных органов, должностных лиц и иных заинтересованных лиц, направленную на общее руководство его деятельностью, с целью получения прибыли и эффективности деятельности.

Анализ последних исследований и публикаций. Рассматривая исторический аспект создания корпоративной системы управления в акционерных обществах Республики Беларусь можно выделить несколько этапов.

Начальным, первым этапом создания системы корпоративного управления акционерными обществами в Республике Беларусь можно считать начало 90-х годов прошлого столетия. Принятие Закона Республики Бе- ларусь от 9 декабря 1992 года "О хозяйственных обществах" [1], Закона Республики Беларусь от 12 марта 1992 года "О ценных бумагах и фондовых биржах" [2], дало законодательную основу созданной в настоящее время системе. В республике были созданы первые акционерные общества, но оставалось неразработанным акционерное право. На этом этапе советы директоров скорее имели номинальный статус наличия в системе управления акционерными обществами.

Вторым этапом создания системы корпоративного управления акционерными обществами способствовало принятие Приказа Министерства Финансов Республики Беларусь № 293 от 18.08.2007г. «О применении Свода правил корпоративного поведения» [3]

Цель статьи - отобразить роль корпоративной системы управления акционерными обществами в Республике Беларусь как инструмента минимизации финансовых рисков.

Изложение основного материала исследования. Способствовало изучению международного опыта корпоративного поведения, правил базирующихся на признанных в международной практике принципах корпоративного управления, разработанных Организацией экономического сотрудничества и развития (ОЭСР). Приказ положил основу нормам корпоративного поведения и требованиям к органам управления акционерными обществами. Им была определена роль эффективной деятельности совета директоров (наблюдательного совета), которая во многом обеспечивается независимостью суждений 
его членов. Для усиления этой функции данным приказом рекомендуется обязательное включение в состав наблюдательного совета определенного количества независимых директоров. Их должно быть не менее $1 / 4$ от состава наблюдательного совета и не менее 3 человек, что способствует формированию объективного мнения наблюдательного совета по обсуждаемым вопросам и способствует укреплению доверия инвесторов к обществу [3]. Независимость директоров необходима от акционеров хозяйственного общества, от исполнительного органа управления для выражения объективной оценки результатов деятельности исполнительных органов общества и принятия обоснованных решений по конфликту интересов, между исполнительными органами общества и акционерами .

Анализ мирового опыта корпоративной системы управления акционерных обществ свидетельствует, что в России и других странах, количество независимых директоров колеблется от 15 до $50 \%$ членов совета директоров(наблюдательного совета) акционерного общества. Это прежде всего требования к эмитентам ценных бумаг, к их корпоративной системе управления. Так в руководстве по листингу на Лондонской бирже для эмитентов класса «премиум» требуется, что бы не менее $50 \%$ совета директоров состояло из независимых директоров. Условиями листинга в формулировке нормы корпоративного управления для эмитентов Московской фондовой биржи содержится обязательное требование о наличии не менее 3 независимых директоров в совете директоров эмитента если их акции отнесены к самой высокой группе акций «A1»; «A2». Для котировки облигаций этого же уровня должно быть не менее 1 независимого директора.

К сожалению нормы приказа Министерства Финансов 2007 года, носили рекомендательный характер, отсутствовало понимание трактовки «независимый директор» и данная норма не нашла должного применения в акционерных обществах этого периода развития корпоративных систем управления в республике.

Третий этап создания системы корпоративного управления акционерными обществами в республике связано с принятием изменений в Банковский кодекс Республики Беларусь, что способствовало Внедрению принципов Базельского Комитета по банковскому надзору [4] в банковской системе Республики Беларусь и закреплению в Банковском Кодексе Республики Беларусь требова- ний по созданию корпоративной системы управления в банках. Банковским Кодексом Республики Беларусь было закреплено обязательное включение в состав наблюдательного совета банка не менее одного независимого директора, создание комитета по аудиту, который он возглавляет. Это получило развитие в постановлениях правления Национального Банка Республики Беларусь: «Инструкция об организации системы управления рисками в банках, небанковских кредитно-финансовых организациях. банковских группах и банковских холдингах» № 550 от 29.10.2012., «Инструкции об организации системы внутреннего контроля в банках, небанковских кредитно-финансовых организациях, банковских группах и банковских холдингах» №557 от 30.10.2012 г.

Банки обязали включить в состав наблюдательного совета не менее 2 независимых директоров, предъявив к ним высокие требования. Свою деловую репутацию они должны были подтвердить аттестацией в Национальном Банке Республики Беларусь. Национальным Банком Республики Беларусь установлен ряд требований к квалификации независимых директоров и их деловой репутации. Это должны быть специалисты высокого уровня, имеющие высшее экономическое или юридическое образование, стаж работы на руководящих должностях в банковской системе. Также это могут быть научные работники, имеющие ученые степени кандидатов и докторов наук занимающиеся актуальными проблемами экономики и финансово-кредитной системы, аудиторы. Для усиления эффективной работы наблюдательного совета, обязательным стало создание, не только комитета по аудиту, но и комитета по рискам, возглавляемые независимыми директорами [5].

Четвертый этап создания системы корпоративного управления акционерными обществами, связан с принятием постановления Государственного комитета по имуществу Республики Беларусь «Об утверждении примерных форм корпоративного кодекса и положений о комитетах при Советах директоров» в 2015 году. В нем был обобщен опыт банковской системы республики и выработаны пути его использования в акционерных обществах с существенной долей государства [6].

Выводы и перспективы дальнейших исследований. Важность обозначенных этапов была закреплена в Методических рекомендациях по организации корпоративного управления в акционерных обществах с учас- 
тием государства, постановлением Министерства экономики и Госимущества 05.07.2016 г. № 45/14 [7]. Таким образом, у акционерных обществ появилась определенная методика создания корпоративного кодекса акционерного общества, позволяющая создавать эффективные системы управления, позволяющие увеличить конкурентоспособность предприятий республики на рынках международного капитала. Путь который прошла Республика Беларусь подтверждает наличие достаточной нормативно правовой базы и передового опыта по созданию эффективных систем корпоративного управления, позволяющих управлять рисками, особенно финансовыми и привлекать международных инвесторов. Данная система способствует развитию фондового рынка и выходу предприятий на международные рынки капитала.

\section{Литература}

1. Закон Республики Беларусь от 09.12.1992 г. № 2020-XII «О хозяйственных обществах» [Электронный ресурс]. - Режим доступа: //http://www.minfin.gov.by/upload/dep

2. Закон Республики Беларусь от 12.03.1992 г. №1512-XII «О ценных бумагах и фондовых биржах» [Электронный ресурс]. Режим доступу: http://www.minfin.gov.by/

3. Приказ Министерства Финансов Республики Беларусь от 18.08.2007 г., № 293 «О применении Свода правил корпоративного поведения» [Электронный ресурс]. - Режим доступу: www.minfin.gov.by/depcen/acts

4. Basel Commmittee on Banking Supervision. Care Prineiples for Effektive Banking Supvision. Bank for Intenational Settlements, September 2012. [Электронный ресурс]. - Режим доступу: www.bis.ord./publ/bebs230.pdf.

5. Рабыко И. Н. Взаимоотношения независимых директоров и банка в системе корпоративного управления / И. Н.Рабыко // Вестник Белорусского государственного экономического университета. - 2015. - №1. - С. 90-96.

6. Постановление Государственного комитета по имуществу Республики Беларусь от 09.07.2015 г. №29 «Об утверждении примерных форм корпоративного кодекса и положений о

\footnotetext{
Стаття надійшла

до редакції : 18.06.2018 p.
}

комитетах при совете директоров (наблюдательном совете) открытого акционерного общества». [Электронный ресурс]. - Режим доступу: http://www.gki.gov.by/about/

7. Постановление Министерства экономики и Государственного имущества от 05.07.2016 г. №45/14 «Методические рекомендации по организации корпоративного управления в акционерных обществах с участием государства». [Электронный ресурс]. - Режим доступу: //https://www.economy.gov.by

\section{References}

1. The Law of the Republic of Belarus of December 9, 1992 № 2020-XII “On Business Societies". Retrieved from: http://www.minfin.gov.by/upload/dep

2. Law of the Republic of Belarus of March 12, 1992 № 1512-XII "On Securities and Stock Exchanges". Retrieved from: http://www.minfin.gov.by/

3. Order of the Ministry of Finance of the Republic of Belarus of August 18, 2007, № 293 "On the Application of the Code of Corporate Conduct Rules". Retrieved from: www.minfin.gov.by/depcen/acts

4. Basel Commmittee on Banking Supervision. Care Prineiples for Effektive Banking Supvision. Bank for Intenational Settlements, September 2012. Retrieved from: www.bis.ord./publ/bebs230.pdf.

5. Rabyko, I. N. (2015). Relationships of non-dependent directors and the bank in the system of corporate governance. Bulletin of the Belarusian State Economic University, 1, 90-96.

6. Resolution of the State Committee on Property of the Republic of Belarus of 09.07.2015 № 29 “On approval of exemplary forms of the corporate code and regulations on committees under the board of directors (supervisory board) of an open joint-stock company". Retrieved from: http://www.gki.gov.by/about/

7. Resolution of the Ministry of Economics and State Property of July 5, 2016 № 45/14 "Methodological Recommendations on the Organization of Corporate Governance in JointStock Companies with Participation of State". Retrieved from: //https://www.economy.gov.by.

$$
\begin{aligned}
& \text { Стаття прийнята } \\
& \text { до друку: 20.11.2018 p. }
\end{aligned}
$$

Бібліографічний опис для цитування :

Рыбако И. Н. Корпоративная система управления акционерными обществами в Республике Беларусь / И. Н. Рыбако // Часопис економічних реформ. - 2018. - № 4 (32). - С. 19-22. 